\title{
Fault Movement Potentials in the Tehran-Semnan Region (North Iran)
}

\author{
Hamideh Noroozpour ${ }^{1}$, Mehran Arian ${ }^{2 *}$, Ali Sorbi ${ }^{3}$ \\ ${ }^{1}$ Department of Geology, Faculty of Science, Payame Noor University, Tehran, Iran \\ ${ }^{2}$ Department of Geology, Science and Research Branch, Islamic Azad University, Tehran, Iran \\ ${ }^{3}$ Department of Geology, Karaj Branch, Islamic Azad University, Karaj, Iran \\ Email: ${ }^{*}$ mehranarian@yahoo.com
}

Received 13 April 2015; accepted 10 May 2015; published 13 May 2015

Copyright (C) 2015 by authors and Scientific Research Publishing Inc.

This work is licensed under the Creative Commons Attribution International License (CC BY).

http://creativecommons.org/licenses/by/4.0/

(c) (i) Open Access

\section{Abstract}

The major Quaternary faults in the Tehran-Semnan region can be classified based on their strikes into three sets: northeast-southwest, northwest-southeast and east-west. In this paper, we use a model to evaluate fault movement potential (FMP). Their theoretical model is based on the relationship between fault geometrical characteristics and regional tectonic stress field. The results show that The Mosha, Emam Zadeh Davood and Pourlcan-Vardij fault zones have high FMP (0.9 or 90\%) and the Parchin fault zone has very low FMP $(0.0$ - 0.1) in the area.

\section{Keywords}

Quaternary Faults, Semnan, Tehran, FMP, Iran

\section{Introduction}

Seismicity is closely related to active Quaternary faults. This attracts many researchers to investigate the quantitative relationships between them. As a new parameter, FMP is defined to quantify earthquake risk along active faults by [1]. Therefore, we use it for evaluation of earthquake risk along Tehran-Semnan region in north of Iran. The landforms in this area are mainly controlled by three sets of Quaternary faults, striking northeast, northwest and east-west, respectively (Figure 1). The activity levels of the main Quaternary faults have been investigated in Tehran-Semnan region, based on [2]-[4].

Previous work regarding these topics was mainly based on seismotectonics and risk analyses [5] [6] without ordering of main Quaternary faults. In this paper, we use a new method [1] to evaluate fault activity by considering the mechanical relationships between fault geometry and regional tectonic stress field. This method has

\footnotetext{
${ }^{*}$ Corresponding author.
} 


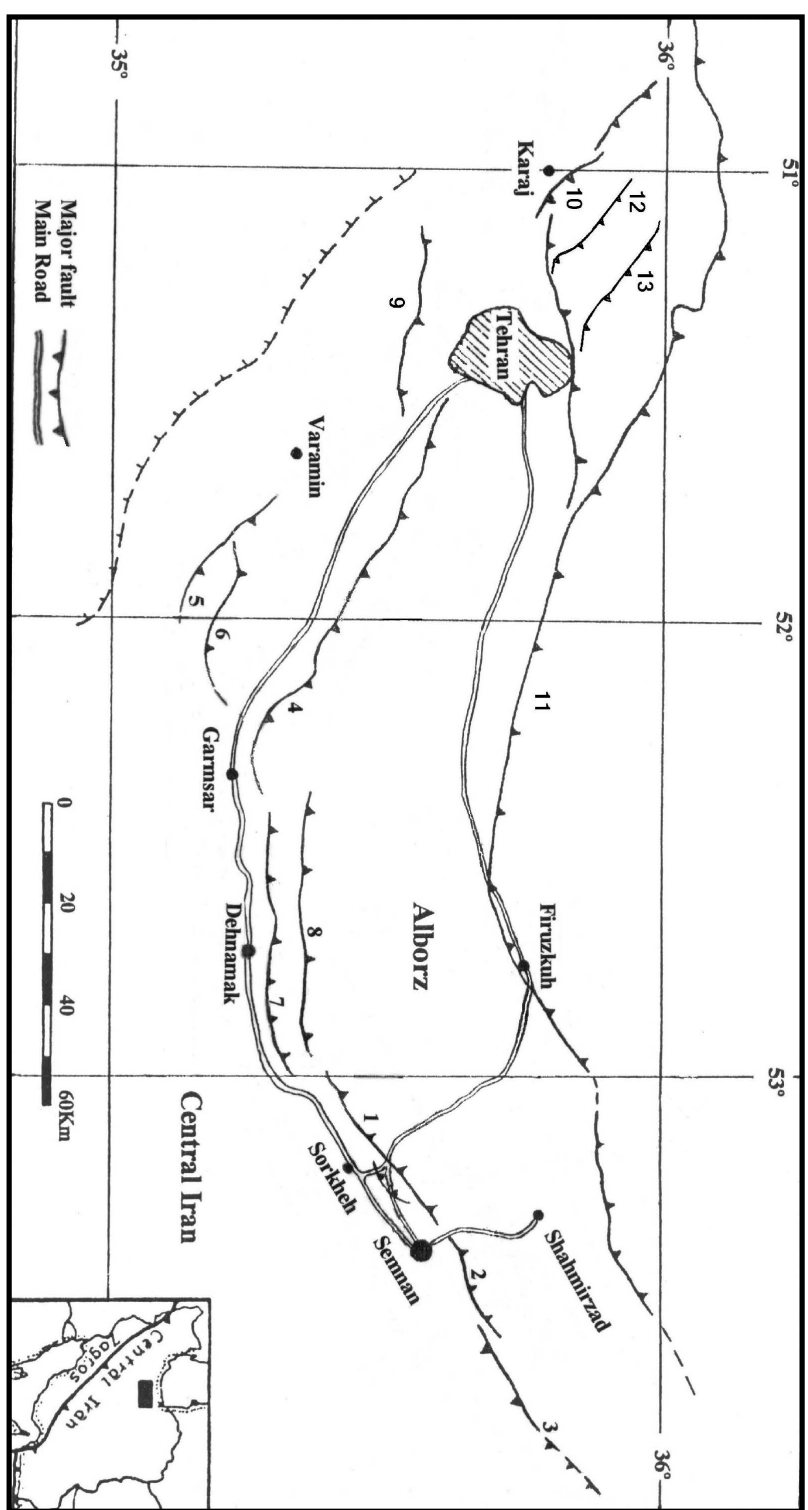

Figure 1. The major faults in Alborz-Central Iran border zone. Numbers in figure are: 1. North Sorkheh fault zone, 2. North Semnan fault zone, 3. Attary fault zone, 4. Parchin fault zone, 5. Pishva fault zone, 6. Kuh-e-Sorkh fault zone, 7. Garmsar fault zone, 8. Sorkheh Kalut fault zone, 9. Kahrizak fault zone, 10. North of Tehran fault zone, 11. Mosha fault zone, 12. Pourkan-Vardij fault zone, 13. EmamZadeh Davood fault zone.

been used to evaluate the fault movement potentials of all the major Quaternary faults in the Tehran-Semnan region in north of Iran.

The study area is located in West-Central Alborz and lesser Caucasus province [7]. Dominant structural trend in West-Central Alborz and lesser Caucasus province is NW-SE. From tectonics view, it contains deformed zone (fold and thrust belt) of Cimmerian miniplate that formed in northern active margin until late Triassic. Then it has rifted by tension in a back arc basin of Neotethyian subduction zone in the south margin of Cimmerian miniplate. Development of that rift stopped in the late Cretaceous and then, renewed in the Eocene by spreading in submarine arc basin of Neotethyian subduction zone. In the other word, this hinterland is result of a magmatic arc system spreading in the evolutional back arc basin. After that, West-Central Alborz and lesser Caucasus hinterland has formed by deformation and regional uplift from SW part of Caspian Sea to Black sea [8] [9]. Also, based on previous work on the salt diapirism [10]-[19] and neotectonics regime in Iran [20], Zagros in south Iran is the most active zone [21]-[35]. Then, Alborz in north Iran [36]-[67] and Central Iran [68]-[78] have 
been situated in the next orders.

\section{Materials and Methods}

Quaternary faults are well developed in the Tehran-Semnan region. They were classified into three sets based on their strikes: northeast, northwest and east west.

\subsection{The Northeast Striking Fault Set}

The northeast striking fault set is the major paleogeographic fault set [79] in studied area. The faults in this set are multistaged active fault inferred to have significant effects on the development of the southern foreland fold and thrust belt of Alborz Mountain. Striking $053^{\circ}-072^{\circ}$ with high dip angles, this fault set can be subdivided into three major faults the North Sorkheh fault zone, the North Semnan fault zone and Attary fault zone.

\subsection{The Northwest Striking Fault Set}

This fault set comprises three fault zones striking $306^{\circ}-324^{\circ}$ with high dip angles. Among them, the Mosha (Figure 2), Parchin and Pishva fault zone are the major Quaternary fault zones. The Emam Zadeh Davood (Figure 3), Pourkan-Vardij (Figure 4) and Kuh-e-Sorkh are a minor Quaternary fault zones.

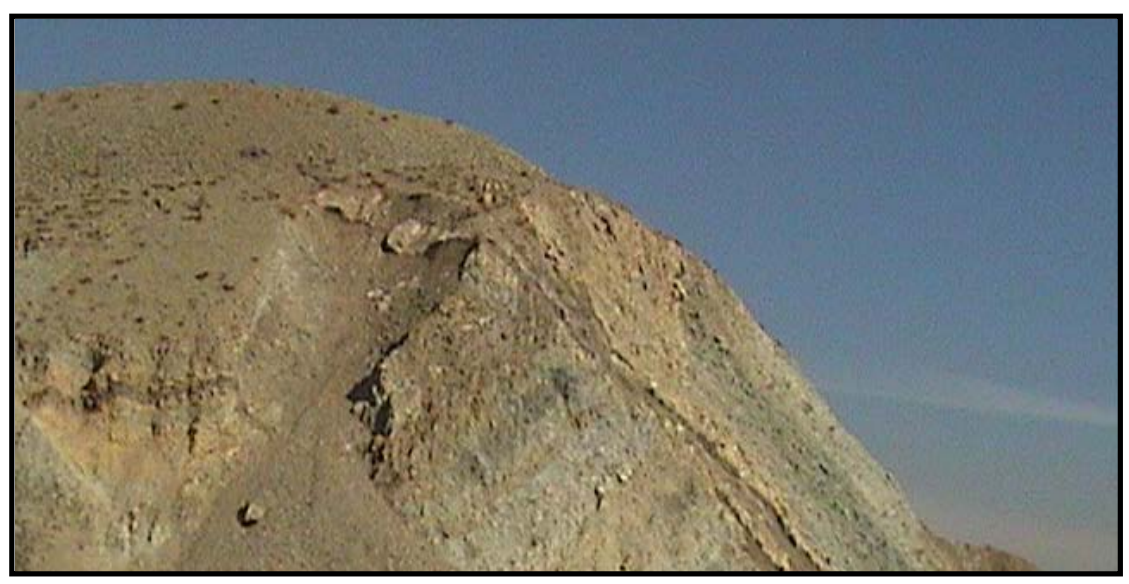

Figure 2. A view of the Mosha fault zone in northwest of Tehran (view to the east).

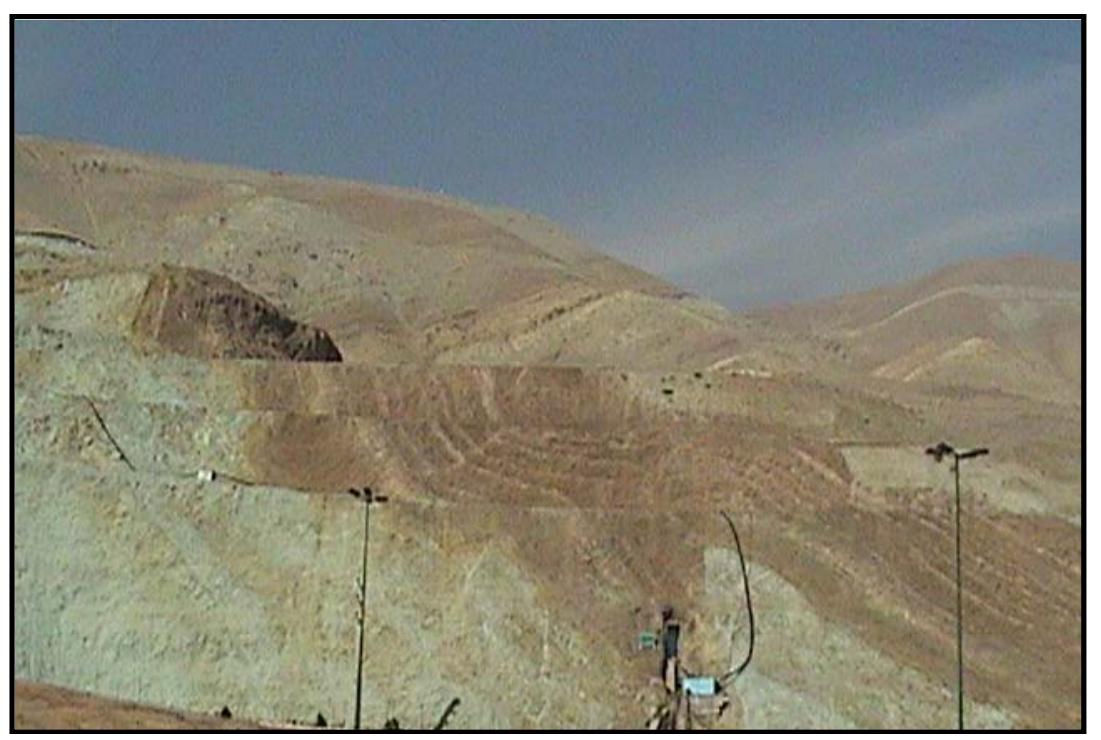

Figure 3. A view of the Emam Zadeh Davood fault zone in northwest of Tehran (view to the northeast). 


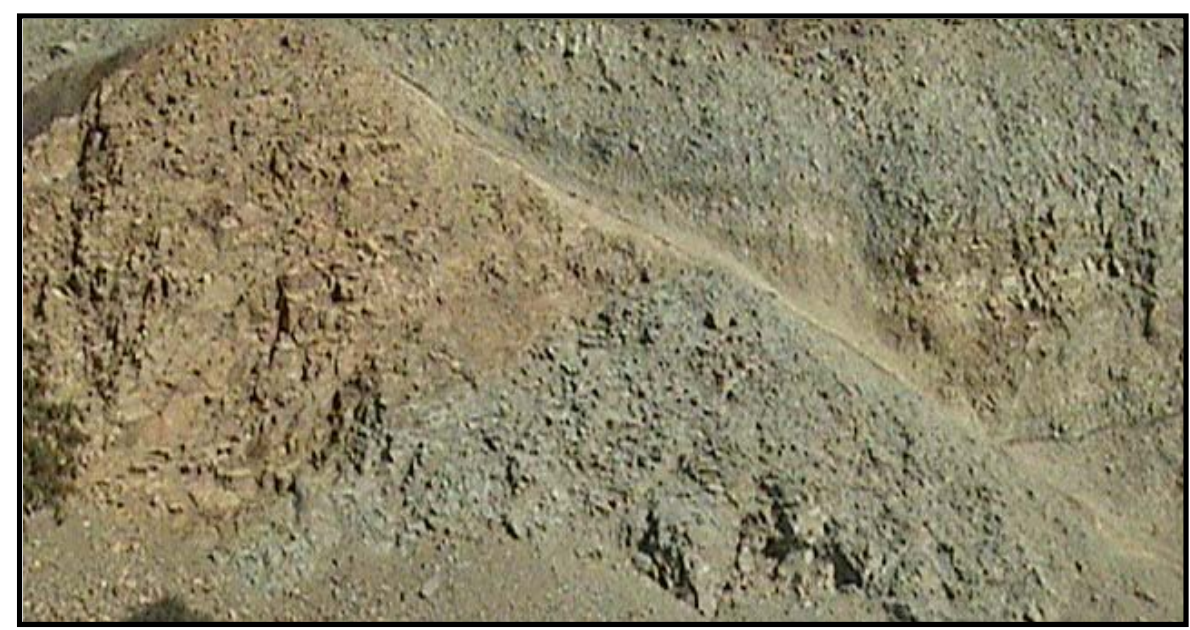

Figure 4. A view of the Pourkan-Vardij fault zone in northeast of Karaj (view to the northwest).

\subsection{The East-West Striking Fault Set}

The faults of this set are well exposed and can be traced intermittently for a long distance (more than $55 \mathrm{~km}$ ) in nearly east-west direction. In this set, there are two major Quaternary fault zones, the North Tehran, Kahrizak, Garmsar and the Sorkheh Kalut fault zone in the north of the Garmsar fault zone.

In summary, all of these fault zones are active in current tectonic regime (CTR) and characterized by microseismic events and geomorphic indices, because they formed mountain front faults system in the southern flank of the Alborz belt.

In the following sections, we will evaluate the earthquake risk along these faults, and discuss which fault is most favored to move under the influence of present-day tectonic stress field. We make this evaluation based on the relationships between tectonic stress orientation and fault geometric properties proposed by [1].

\subsection{Theoretical Model for Analysis of Fault Movement Potential}

The fault movement potential (FMP) is closely related to tectonic stress $(\sigma)$, fault plane geometry (G) and the physical property of the medium within and on both sides of the fault (P). FMP is the function of these factors [1]:

$$
F M P=f(s, G, P)
$$

Although a geological medium is generally heterogeneous and very complicated, however it can be taken as homogeneous and isotropic in statistical view of our case. This region is the border zone of Alborz-Central Iran structural zones and thus, geological concepts and tectonic settings are similar along it. Based on this consideration, and for the purpose of simplification in the theoretical derivation, [1] also take the geological medium containing the faults as a homogeneous, isotropic and elastic material. Therefore fault movement potential can be simplified as:

$$
F M P=f(s, G)
$$

Finally, according to [80] and [81] researches, [1] define FMP to quantify the relationship between fault movement potential as a normalized factor by the following equations:

$$
F M P= \begin{cases}0 & \theta \in\left(0^{\circ}, 30^{\circ}\right) \\ \frac{\theta-60^{\circ}}{30^{\circ}} & \theta \in\left(30^{\circ}, 60^{\circ}\right) \\ 1-\frac{\theta-60^{\circ}}{30^{\circ}} & \theta \in\left(60^{\circ}, 90^{\circ}\right)\end{cases}
$$


$\theta$ is the angle between the regional maximum principal compressive stress orientation $\left(\sigma_{1}\right)$ and the normal line of fault plane.

\subsection{Regional Tectonic Stress Orientations}

Tectonic stress means an additional stress to lithostatic stress state, in the other words, the part of stress deviated from lithostatic stress. Earthquake focal mechanism solution is one of the commonly used methods in the study of contemporary tectonic stress field.

Therefore, we use results of [82]-[84] and our field study to estimate the regional maximum principal compressive stress orientation $\left(\sigma_{1}\right)$. The statistical result shows that the average attitude of $\sigma_{1}$ is $10^{\circ}, 207^{\circ}$.

\section{Results and Discussion}

The fault movement potential of the major Quaternary faults in the Tehran-Semnan region are calculated using the Equations (3) and the regional stress orientation as well as the fault plane attitudes. The results are shown in Table 1.

1) The northeast striking fault set have large angle between the normal to the fault planes and the compressive principal stress along these fault zones. The fault movement potential of this fault set ranges from medium to high, suggesting that this fault set has the sufficient potential for generating destructive earthquakes, especially along the north Sorkheh) and north Semnan fault zone.

2) The northwest striking fault set have small to medium angle between the normal to the fault planes and the compressive principal stress along these fault zones. The fault movement potential of this fault set ranges from medium to high, suggesting that this fault set has the sufficient potential for generating destructive earthquakes.

3) The east-west striking fault set have medium angle between the normal to the fault planes and the compressive principal stress along these fault zones. The fault movement potential of this fault set is medium, suggesting that this fault set has not the sufficient potential for generating destructive earthquakes.

Although, many earthquakes occurred at the intersection of the Garmsar fault zone with the southeast continuation of Parchin fault zone and the intersection of the Mosha fault zone with the northeast continuation of North Tehran fault zone (Figure 5).

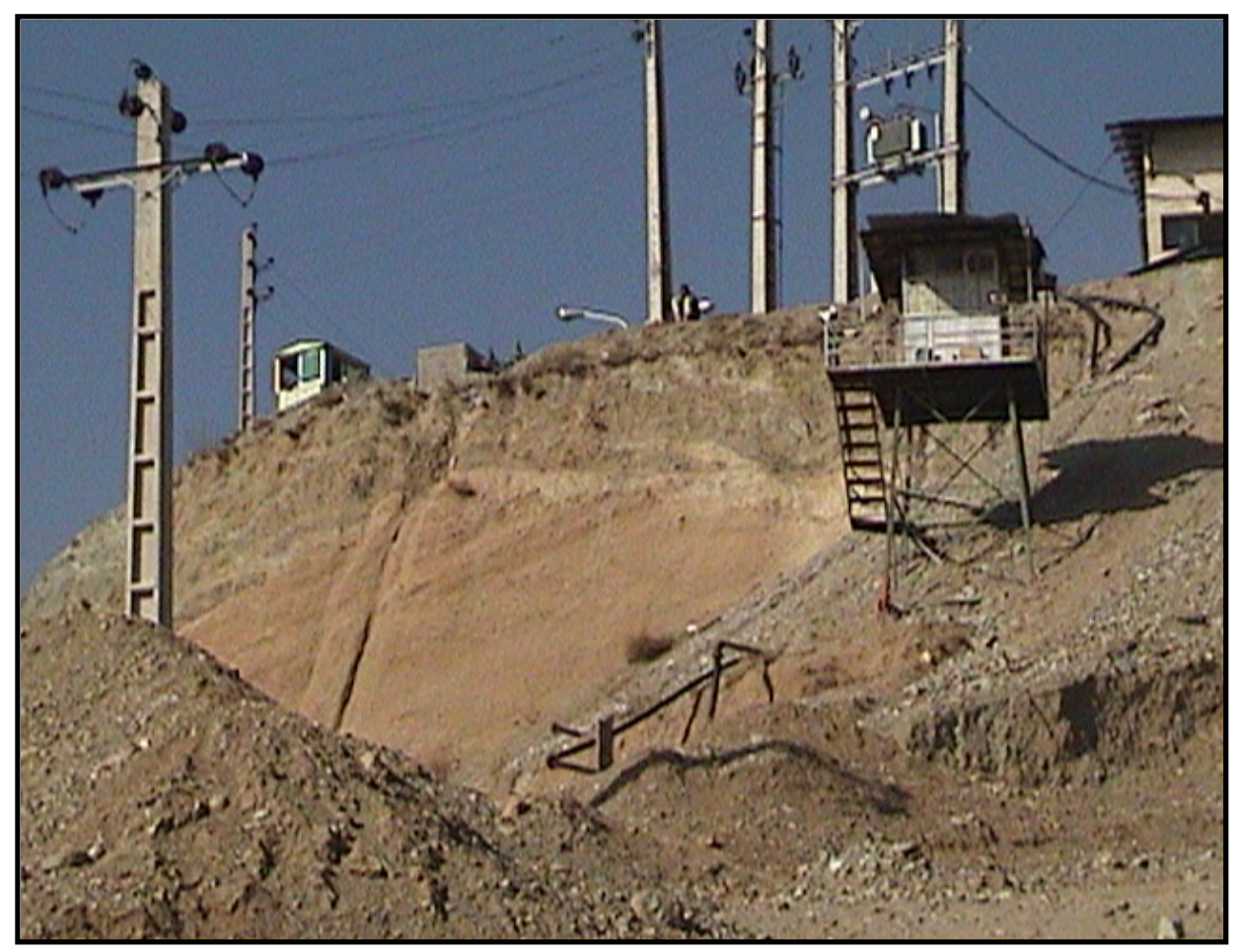

Figure 5. A view of the North Tehran fault zone in north (Hesarak) Tehran (view to the north). 
Table 1. The calculation of fault movement potential in the Tehran-Semnan region.

\begin{tabular}{|c|c|c|c|c|}
\hline No & Name of fault zone & Fault set & $\theta$ & FMP \\
\hline 1 & North Sorkheh & North-east striking & $65^{\circ}-66^{\circ}$ & 0.8 \\
\hline 2 & North Semnan & North-east striking & $64^{\circ}-65^{\circ}$ & 0.8 \\
\hline 3 & Attary & North-east striking & $70^{\circ}-78^{\circ}$ & $0.4-0.6$ \\
\hline 4 & Parchin & North-west striking & $28^{\circ}-33^{\circ}$ & $0.0-0.1$ \\
\hline 5 & Pishva & North-west striking & $36^{\circ}-40^{\circ}$ & $0.2-0.3$ \\
\hline 6 & Kuh-e-Sorkh & North-west striking & $40^{\circ}-51^{\circ}$ & $0.3-0.7$ \\
\hline 7 & Garmsar & East-west striking & $43^{\circ}-48^{\circ}$ & $0.4-0.6$ \\
\hline 8 & Sorkheh kalut & East-west striking & $42^{\circ}-46^{\circ}$ & $0.4-0.5$ \\
\hline 9 & Kahrizak & East-west striking & $68^{\circ}$ & 0.7 \\
\hline 10 & North Tehran & East-west striking & $70^{\circ}-82^{\circ}$ & $0.3-0.7$ \\
\hline 11 & Mosha & North-west striking & $50^{\circ}-88^{\circ}$ & $0.1-0.9$ \\
\hline 12 & Pourkan-Vardij & North-west striking & $55^{\circ}-57^{\circ}$ & $0.8-0.9$ \\
\hline 13 & Emam Zadeh Davood & North-west striking & $50^{\circ}-52^{\circ}$ & $0.7-0.9$ \\
\hline
\end{tabular}

Therefore, it seems that, the northwest striking fault set has got more potential for movement in the current tectonic regime related to other fault sets. The Emam Zadeh Davood, Pourkan-Vardij and Mosha have got the highest movement potential (to 90 percent).

Based on [85], the study area has situated in Central Alborz seismotectonic province. It has got $\mathrm{b}=0.71$ and $\mathrm{M}_{\max }=7.8$. Dominant structural trend in Central Alborz province is NE-SW in eastern part and NW-SE in western part. Focal mechanisms of many earthquakes are sinistral strike slip faulting such as Manjil (Ms = 7.3, 1990) and reversed with sinistral strike slip component such as Boien Zahra (Ms = 7.2, 1962).

Central Alborz province has moderate to high earthquakes with low frequency, long repeat time and down to $20 \mathrm{Km}$ focal depth. Intensity of earthquakes is in high levels. The most important seismic hazards in Central Alborz province that contains large cities such as Tehran, Ghazvin and Zanjan are landslide in high regions, settlement in some plains, surface faulting and volcanic hazards around Damavand cone.

\section{Conclusions}

According to this research, the contemporary movements potential along fault zones of various orientations are different under the action of present-day regional north-northeast compressive stress field in studied region. The Mosha, Emam Zadeh Davood and Pourkan-Vardij fault zones have high FMP (0.9\% or 90\%) and the Parchin fault zone has very low FMP $(0.0-0.1)$.

The region where the SE continuation of the northwest striking Parchin fault zone intersects the east-west striking Garmsar fault zone and the NE continuation of the north Tehran fault intersects the Mosha fault zone prone to big earthquakes.

\section{Acknowledgements}

This work has funded by the Department of geology, Islamic Azad University, Science and Research branch, Tehran, Iran. Also, Special thanks to vice-president for research in Science and Research branch, Tehran.

\section{References}

[1] Lee, C.F., Hou, J.J. and Ye, H. (1997) The Movement Potential of the Major Faults in Hong Kong Area. Episodes, 20, 227-231.

[2] Arian, M. and Maleki, R. (2008) Neotectonics. Farazamin Research Center, Tehran, 150. 
[3] Pourkermani, M. and Arian, M. (1998) Seismicity of Iran. Shahid Beheshti University Press, Tehran, 212.

[4] Pourkermani, M. and Arian, M. (1997) Seismotectonics. Dez Ab Consulting Engineers Company Press, Tehran, 270.

[5] Berberian, M., Qorashi, M., Shoja-Taheri, J. and Talebian, M. (1993) Seismotectonic and Earthquake-Fault Hazard Investigations in the Semnan Region. 2nd Edition, Geological Survey of Iran, Rep. No. 56.

[6] Berberian, M., Qorashi, M., Arzhang-Ravesh, B. and Mohajer-Ashjai, A. (1996) Seismotectonic and EarthquakeFault Hazard Investigations in the Tehran Region. Geological survey of Iran, Rep. No. 63.

[7] Arian, M. (2013) Physiographic-Tectonic Zoning of Iran’s Sedimentary Basins. Open Journal of Geology, 3, 169-177. http://dx.doi.org/10.4236/ojg.2013.33020

[8] Qorashi, M. and Arian, M. (2011) Tectonics of Iran. Geologic Survey of Iran, Tehran, 336 p.

[9] Arian, M. (2011) Basement Tectonics and Geology of Iran. Asar Nafis Press, Qum, 300 p.

[10] Arian, M. (2011) A Preface on Salt Diapirism of Iran. Asar Nafis Press, Qum, 309 p.

[11] Arian, M. and Noroozpour, H. (2015) The Biggest Salt-Tongue Canopy of Central Iran. Open Journal of Geology, 5, 55-60. http://dx.doi.org/10.4236/ojg.2015.52005

[12] Asadian, F., Pourkermani, M. and Arian, M. (2007) Tectonic Geomorphology of Salt Structures in the GarmsarLasjerd Area. Geographical Research, 39, 75-84.

[13] Pourkermani, M. and Arian, M. (1997) Salt Domes of Central Iran. Journal of Humanities, 3, 29-41.

[14] Arian, M. (2012) Salt Diapirism and Tectonics. 2nd Edition, Asar Nafis Press, Qum, 319 p.

[15] Arian, M. and Noroozpour, H. (2015) Tectonic Geomorphology of Iran's Salt Structures. Open Journal of Geology, 5, 61-72. http://dx.doi.org/10.4236/ojg.2015.52006

[16] Asadian, F. and Arian, M. (2009) Identification of Diapiric Provinces of Central Iran through Geological and Geographical Analysis. International Journal of Agriculture Environment \& Biotechnology, 2, 3443-3451.

[17] Arian, M. (2012) Clustering of Diapiric Provinces in the Central Iran Basin. Carbonates and Evaporites, 27, 9-18. http://dx.doi.org/10.1007/s13146-011-0079-9

[18] Pourkermani, M. and Arian, M. (1998) Tectonic Geomorphology of Salt Domes in West of Zanjan Province, Iran. Geography Research, 47, 44-53.

[19] Arian, M. and Feizi, F. (2010) The Significance of Faulting on the Surficial Spreading of Evaporitic Deposits in the Varamin-Semnan Area. Journal of Earth and Resources, 3, 1-20.

[20] Arian, M. (2011) Middle East Tectonics. Asar Nafis Press, Qum, 236 p.

[21] Arian, M. and Aram, Z. (2014) Relative Tectonic Activity Classification in the Kermanshah Area, Western Iran. Solid Earth, 5, 1277-1291. http://dx.doi.org/10.5194/se-5-1277-2014

[22] Mashal, M., Kermani, M.P., Charchi, A., Almasian, M. and Arian, M. (2013) Pattern of Structural Geology Underground in Eastern of North Dezfol Embayment. Advances in Environmental Biology, 7, 260-268.

[23] Pazhoohan, M., Arian, M., Ghorashi, M. and Khosrotehrani, K. (2014) A Study of Drainage Pattern Responses to Active Tectonics in Tadvan Region, SW Iran. Geodynamics, 1, 36-41.

[24] Rahimi, N. and Arian, M. (2014) Tectonic Geomorphplogy of Hamedan-Sosangerd Region, West Iran. Advances in Environmental Biology, 8, 119-124.

[25] Arian, M. and Hashemi, A. (2008) Seismotectonic Zoning in the Zagros. Journal of Sciences (Islamic Azad University), 18, 63-76.

[26] Arian, M., Ahmadnia, A., Qorashi, M. and Pourkermani, M. (2002) Structural Analysis of Mengharak Transcurrent Fault System in Zagros, Iran. Special Geo 2002 Conference Issue Geoarabia, 7, 209-210.

[27] Arian, M., Qorashi, M., Pourkermani, M. and Ahmadnia, A. (2003) Fractal Analysis of Mengharak Transcurrent Fault System in Zagros, in Iran. Abstracts of 4th International Conference on Seismology and Earthquake Engineering, Tehran, 12-14 May 2003, 23.

[28] Baharvand, S., Pourkermani, M., Ajalloian, R., Arian, M. and Nouryazdan, A.R. (2010) Seymareh Landslide and Its Role in Environmental and Geomorphologic Changes of the Pole-Dokhtar Area. Journal of the Earth, 4, 13-24.

[29] Abdideh, M., Qorashi, M., Rangzan, K. and Arian, M. (2011) Assessment of Relative Active Tectonics Using Morphometric Analysis, Case Study of Dez River (Southwestern, Iran). Geosciences, 20, 33-46.

[30] Arian, M., Qorashi, M., Pourkermani, M. and Ahmadnia, A. (2006) The Structural Significance Kareh Bas Transcurrent Fault System in the Zagros Fold and Thrust Belt. Journal of Geosciences, Geological Survey of Iran, 15, 126-133.

[31] Khodabakhshnezhad, A., Arian, M. and Pourkermani, M. (2008) The Elements of Fold Style Analysis in the Asmari Anticline (Zagros). Journal of Sciences (Islamic Azad University), 69, 131-140. 
[32] Arian, M., Pourkermani, M., Khodabakhshnezhad, A. and Noroozpour, H. (2011) Investigation of Oil Trap in the Asmari Anticline (Zagros, Iran). Indian Journal of Science and Technology, 4, 1696-1699.

[33] Khodabakhshnezhad, A., Arian, M. and Pourkermani, M. (2015) Folding Mechanism in the Asmari Anticline, Zagros, Iran. Open Journal of Geology, 5, 197-208.

[34] Khodabakhshnezhad, A., Arian, M. and Pourkermani, M. (2008) The Elements of Fold Style Analysis in the Asmari Anticline (Zagros). Journal of Sciences (Islamic Azad University), 18, 129-138.

[35] Arian, M. and Mohammadian, R. (2011) Analysis of Fractures in the Asmari Reservoir of Marun Oil Field (Zagros). Geosciences, 20, 87-96.

[36] Arian, M., Maleki, Z. and Noroozpour, H. (2011) Cenozoic Diastrophism and Deformational Events in the East Central Alborz. Journal of Basic and Applied Scientific Research, 1, 2394-2400.

[37] Feizi, F., Arian, A. and Rahmani, R. (2007) Seismotectonic Zoning in the Eastern Part of the Central Alborz. Journal of Sciences (Islamic Azad University), 17, 151-164.

[38] Khavari, R., Arian, M. and Ghorashi, M. (2009) Neotectonics of the South Central Alborz Drainage Basin, in NW Tehran, N Iran. Journal of Applied Sciences, 9, 4115-4126. http://dx.doi.org/10.3923/jas.2009.4115.4126

[39] Arian, M. and Bagha, N. (2012) Active Tectonics of Tehran Area, Iran. Journal of Basic and Applied Scientific Research, 2, 3805-3819.

[40] Bagha, N., Arian, M., Ghorashi, M., Pourkermani, M., El Hamdouni, R. and Solgi, A. (2014) Evaluation of Relative Tectonic Activity in the Tehran Basin, Central Alborz, Northern Iran. Geomorphology, 213, 66-87. http://dx.doi.org/10.1016/j.geomorph.2013.12.041

[41] Arian, M. and Feizi, F. (2005) Application of Geomorphic Indices to the Assessment of Relative Tectonic Activity Levels in the Alborz-Central Iran Border Zone (from the East of Varamin to the East of Semnan). Journal of Sciences (Islamic Azad University), 15, 378-403.

[42] Arian, M., Bagha, N., Khavari, R. and Noroozpour, H., (2012) Seismic Sources and Neo-Tectonics of Tehran Area (North Iran). Indian Journal of Science and Technology, 5, 2379-2383.

[43] Moghimi, H., Arian, M. and Sorbi, A. (2015) Fault Movement Potential of Marzanabad Area, North Alborz, Iran. Open Journal of Geology, 5, 126-135. http://dx.doi.org/10.4236/ojg.2015.53012

[44] Arian, M. and Pourkermani, M. (2004) Tectonic Elements of South Flank in the East-Central Alborz Mountain. Journal of Science (Kharazmi University), 4, 359-368.

[45] Arian, M. and Qorashi, M. (2006) The Movement Potential Evaluation of the Major Quaternary Faults in Alborz-Central Iran Border Zone, from the East of Tehran to the East of Semnan. Journal of Geosciences, Geological Survey of Iran, 15, 184-188.

[46] Poroohan, N., Pourkermani, M. and Arian, M. (2013) An Assessment of Relationship in F-Parameter and Paleostress Fields in Heterogeneous Lithologies: Roudbar Area (Northwest of Iran). Australian Journal of Basic \& Applied Sciences, 7, 933-942.

[47] Poroohan, N., Poukermani, M. and Arian, M. (2009) An Assessment on Correlations of Seismotectonic Parameters Preceding and Following Roudbar-Manjil Earthquake (Gilan, North of Iran). Australian Journal of Basic \& Applied Sciences, 3, 2643-2652.

[48] Farrokhnia, A.R., Pirasteh, S., Pourkermani, M. and Arian, M. (2011) Geo-Information Technology for Mass Wasting Hazard Zonation: Central-West Alborz-Iran. Disaster Advances, 4, 24-33.

[49] Khavari, R., Ghorashi, M. and Arian, M. (2009) Assessment of Relative Active Tectonics, South Central Alborz (North Iran). EGU General Assembly Conference, Abstracts 11, Vienna, 19-24 April 2009, 1137.

[50] Sorbi, A., Arian, M. and Pourkermani, M. (2009) The Movement Potential Evaluation of the Major Quaternary Faults in Tehran Quadrangle. Journal of the Earth, 19, 176-182.

[51] Feizi, F. and Arian, M. (2006) The Classification of Thrust Fronts in the Alborz-Central Iran Border Zone from the East of Varamin to the East of Semnan. Journal of Sciences (Islamic Azad University), 16, 75-87.

[52] Keynezhad, A., Pourkermani, M., Arian, M. and Saeedi, A. (2011) Dynamic Analysis of Fractures in North of TorudMoalleman Area (Central Iran, East South of Damghan). Geosciences, 20, 3-16.

[53] Arian, M. and Pourkermani, M. (2004) Structural Significance of North Semnan and Attary Faults in Alborz-Central Iran Border Zone. Journal of Sciences (Islamic Azad University), 14, 4551-4569.

[54] Arian, M. and Pourkermani, M. (2005) Cenozoic Diastrophism and Deformational Events in the Southern Flank of Central-East Alborz. Journal of Earth Sciences (Shahid Beheshti University, Sistan and Baluchestan University), 10, 43-51.

[55] Arian, M., Pourkermani, M., Qorashi, M. and Ghasemi, M.R. (2003) North Semnan Fault System and Its Role on Ba- 
sin Division. 8th Symposium of Geological Society of Iran (Shahrood University of Technology), 11-17.

[56] Pourkermani, M. and Arian, M. (2001) Structural Geomorphology of Northeastern Kurdistan, Sistan and Baluchestan University. Journal of Humanities, 7, 37-48.

[57] Mardani, Z., Ghorashi, M. and Arian, M. (2011) Geomorphic Signatures of Active Tectonics in the Talaghan Rud, Shah Rud and Sefidrud Drainage Basins in Central Alborz, Niran. Geosciences, 20, 159-166.

[58] Sorbi, A., Arian, M. and Pourkermani, M. (2011) The Application of Geomorphic Indices to the Assessment of Relative Tectonic Activity Levels in Tehran Quadrangle. Journal of the Earth, 6, 1-9.

[59] Khavari, R., Ghorashi, M., Arian, M. and Khosrotehrani, K. (2010) Geomorphic Signatures of Active Tectonics in the Karaj Drainage Basin in South Central Alborz, N Iran. Geosciences, 19, 67-74.

[60] Javadi Mousavi, E. and Arian, M. (2015) Tectonic Geomorphology of Atrak River, NE Iran. Open Journal of Geology, 5, 106-114. http://dx.doi.org/10.4236/ojg.2015.53010

[61] Nouri, R., Jafari, M.R., Arian, M., Feizi, F. and Afzal, P. (2013) Correlation between Cu Mineralization and Major Faults Using Multifractal Modelling in the Tarom Area (NW Iran). Geologica Carpathica, 64, 409-416. http://dx.doi.org/10.2478/geoca-2013-0028

[62] Nouri, R., Jafari, M.R., Arian, M., Feizi, F. and Afzal, P. (2013) Prospection for Copper Mineralization with Contribution of Remote Sensing, Geochemical and Mineralographical Data in Abhar 1:100,000 Sheet, NW Iran. Archives of Mining Sciences, 58, 1071-1084. http://dx.doi.org/10.2478/amsc-2013-0074

[63] Nouri, R., Afzal, P., Arian, M., Jafari, M. and Feizi, F. (2013) Reconnaissance of Copper and Gold Mineralization Using Analytical Hierarchy Process (AHP) in the Rudbar 1:100,000 Map Sheet, Northwest Iran. Journal of Mining and Metallurgy A: Mining, 49, 9-19.

[64] Arian, M. and Nouri, R. (2015) Lineament Tectonics and Mineralizatin in Tarom Area, North Iran. Open Journal of Geology, 5, 115-124. http://dx.doi.org/10.4236/ojg.2015.53011

[65] Feizi, F. and Arian, M. (2011) The Role of Structural Controllers in Geneses of Copper Deposits in 1:50000 Map of Saiin Qaleh. Journal of Sciences (Islamic Azad University), 21, 1-10.

[66] Bahiraee, S, Arian, M., Qorashi, M., Solgi, M. (2015) The Movement Potential Evaluation of the Mosha Fault (the West of Firoozkuh to the Shahrestanak). Geosciences, 24, 123-126.

[67] Bagha, N., Ghorashi, M., Arian, M., Pourkermani, M. and Solgi, A. (2015) Neotectonic Analysis of Mosha-North Tehran Fault Zone, Based on Morphotectonic Features, Central Alborz, Northern Iran. Geosciences, 24, 41-52.

[68] Arian, M., Toudeshki, V.H. and Noroozpour, H. (2011) Active Tectonics of Qezel Ozan River Basin, NW Iran. Journal of Applied Environmental and Biological Sciences, 1, 291-295.

[69] Housini Toudeshki, V., Pourkermani, M., Arian, M. and Khosrotehrani, K.H. (2011) Influence of Structures on the Ghezel Ozan River. Geosciences, 21, 55-60.

[70] Housini Toudeshki, V. and Arian, M. (2011) Morphotectonic Analysis in the Ghezel Ozan River Basin, NW Iran. Journal of Geography and Geology, 3, 258-260. http://dx.doi.org/10.5539/jgg.v3n1p258

[71] Pourkermani, M. and Arian, M. (1997) Salt Domes of Central Iran. Journal of Humanities University of Sistan and Balouchestan, 3, 29-41.

[72] Arian, M., Pourkermani, M., Sistanipour, A. and Noroozpour, H. (2011) Kinematic Significance of Fold- and FaultRelated Fracture Systems in the Rafsanjan’s Northeast Highlands (Central Iran). Journal of Basic and Applied Scientific Research, 1, 3398-3406.

[73] Arian, M., Pourkermani, M., Sistanipour, A. and Noroozpour, H. (2011) Seismicity and Fault Segmentation of BafqBaghin Fault System (Central Iran). Journal of Applied Environmental and Biological Sciences, 1, 382-396.

[74] Javadi Mosavi E., Arian, M., Ghorashi, M. and Nazemi, M. (2012) Measurements of Geomorphic Indices in Tabas Area. Journal of the Earth, 7, 213-225.

[75] Arian, M. (2010) Earthquake-Fault Hazard Investigations in the Kerman Quadrangle. Journal of Sciences (Islamic Azad University), 19, 176-182.

[76] Javadi Mosavi, E. and Arian, M. (2015) Neotectonics of Tabas Area, Central Iran by Index of Active Tectonics (IAT). Open Journal of Geology, 5, 209-223. http://dx.doi.org/10.4236/ojg.2015.54019

[77] Alizadeh, H., Arian, M., Lotfi, M., Ghorashi, M. and Ghorbani, M. (2015) Determination of Porphyry Copper Deposit Locations Using Photo Lineament Factor in Northern Parts of the Dehaj-Sardoiyeh Belt. Geosciences, 24, $247-252$.

[78] Jamalian Daryani, N., Arian, M. and Rashidnezhad Omran, N. (2015) Tectonics and Mineralization of Copper in the Ardestan-Kahang Area, Central Iran by Remote Sensing. Open Journal of Geology, 5, 188-196. http://dx.doi.org/10.4236/ojg.2015.54017

[79] Alavi Naini, M. (1972) Etude geologique de la region de Djam. Geological Survey of Iran, Tehran. 
[80] Lokajicek, T., Spicak, A. and Waniek, L. (1988) Tectonic Stress Orientation and the Seismic Regime of a Single Fault. Tectonophysics, 152, 297-302. http://dx.doi.org/10.1016/0040-1951(88)90055-8

[81] He, S.H. (1989) The Effect of Orientation and Level of Principal Stress on Fault Movement. Crustal Deformation and Earthquake, 9, 44-52.

[82] Jackson, J.A., Haines, A.J. and Holt, W.E. (1995) The Accommodation of Arabia-Eurasia Plate Convergence in Iran. Journal of Geophysical Research: Solid Earth, 100, 15205-15219. http://dx.doi.org/10.1029/95JB01294

[83] Jackson, J.A., Priestley, K., Allen, M. and Berberian, M. (2002) Active Tectonics of the South Caspian Basin. Geophysical Journal International, 148, 214-242. http://dx.doi.org/10.1046/j.1365-246X.2002.01005.X

[84] Allen, M.B., Ghassemi, M.R., Shahrabi, M. and Qorashi, M. (2003) Accommodation of Late Cenozoic Oblique Shortening in the Alborz Range, Northern Iran. Journal of Structural Geology, 25, 659-672. http://dx.doi.org/10.1016/S0191-8141(02)00064-0

[85] Arian, M. (2010) Applied Seismotectonics. Farazamin Press, Tehran, 304 p. 